\title{
Brazilian Police Officers Killed in the Line of Duty: Daily Life of a Violent Reality
}

\author{
Moisés Costa da Conceição ${ }^{1}$ Jaime Luiz Cunha de Souza ${ }^{2}$ João Francisco Garcia Reis ${ }^{3}$ \\ 1. Moisés Costa da Conceição is a Lieutenant-Colonel of the Police and a master's student of Public Security at \\ the Federal University of Para - Brazil \\ 2.Jaime Luiz Cunha de Souza has a Ph.D. in Social Sciences and is currently a professor in the Graduate Studies \\ Program Public Security of the Faculty of Social Sciences of the Federal University of Pará - Brazil \\ 3.João Francisco Garcia Reis is a retired major of the Police of the State of Pará. He earned a PhD in Sustainable \\ Development at the Center for Amazonian Studies of the Federal University of Pará (NAEA) - Brazil
}

\begin{abstract}
This paper presents data on the causes and circumstances of on-duty police deaths in Pará state, Brazil. We specifically analyzed deaths occurring from January 2010 to December 2017. Fifty-two deaths were examined using the database of the Secretary of Intelligence and Criminal Investigations (Siac) of Pará State Secretary for Public Security (Segup) and the investigative procedures undertaken by the internal inspector of the Pará Military Police and by the Homicide Division of Pará Civil Police. Results show that in a little less than fifty percent of all cases, on-duty police deaths are not directly related to direct confrontations with criminals even when they occur during work shifts. Despite the common discourse that police are killed by criminals seeking revenge, or because their equipment, especially guns are robbed, the number and nature of police deaths during the period of investigation does not corroborate these speculations.
\end{abstract}

Keywords: Police deaths. Improper conduct. Performance. Execution. Accidents.

DOI: $10.7176 /$ RHSS/10-4-05

Publication date: February $29^{\text {th }} 2020$

\section{Introduction}

Violence is currently one of the most difficult problems facing Brazil. Many factors contribute to this scenario, including: deficiencies in policing operations, recent expansion of the scope of crime modalities, the technological and operational lag of the police forces, and the increasing attraction of youth to criminal activity. These factors, isolated or taken together, constitute the complex environment from which new and old matrices of violence are generated and reinforced. According the Brazilian Publication titled: Twelfth Annual Report on Brazilian Public Security $\left(12^{\circ}\right.$ Anuário Brasileiro de Segurança Pública), based on data from 2017, approximately 63,880 people were killed through intentional violence, or rather, were murdered. In Pará state alone, this year (2017), the number of murder victims reached 3,820 people.

Pará is one of nine states that make-up the Northern region of Brazil (referred to as the Norte do Brasil). The region has a territorial extension of $3,870,000 \mathrm{~km}^{2}$ and a population of approximately of 18 million inhabitants. Eighty percent of the territory is occupied by the Amazon Rainforest. More than eight million people live in Pará, equivalent to approximately $44 \%$ of the region's population. In 2018, the state capital, Belém, had a population of 1,485,732 residents. Like all Brazilian states, Pará concentrates within its territory a gamut of inequalities and social problems that have historically fostered criminality and violence in this part of the country (Reis \& Souza, 2016).

Since late 2000s, Pará has experienced rising crime rates, with especially high murder rates, mainly due to the intensification of territorial disputes and drug trade escalation (Souza \& Reis, 2017). Within this context of public insecurity and high mortality, more on and off-duty police deaths are occurring - something relatively uncommon until recent years. This has led to the popular belief that police are being intentionally hunted by criminals. Analysis of mortality data, however, allows us to identify other factors that entirely or partially disprove this claim. While police officer deaths provoke a devastating effect on the population's confidence in State capacity to guarantee safety, many deaths have no direct relation to deliberate criminal activities.

According to media, common sense understandings, and some sectors of the Pará Military Police (Policia Militar do Estado do Pará - PMPA), police are victims of a "hunt" promoted by criminals in Pará who seek to intimidate police, constraining state authorities with fear and violence. According to these speculations, offenders attack to retaliate against policing and crime fighting activities, especially when such actions interfere in the dynamics of illegal activities. Retaliation against measures to curtail drug trafficking, in this view, are particularly common. In this article we critically investigate these arguments and present data that allows for an objective analysis of the circumstances under which police deaths occur. At the same time, we evaluate the extent to which speculation about the alleged police hunt is coherent with reality.

In most countries, law enforcement is considered one of the most dangerous occupations (Tiesman, Hendricks, Bell \& Amandus, 2010) and risk is considered inherent to the policing profession (Schouten \& Brennan, 2016). 
However, data from various sources indicate that risks posed to officers are often unrelated to direct conflict between police and offenders. Our task, therefore, concentrated on highlighting alternative explanations to those commonly provided. We begin with a review of literature that discusses on-duty police deaths and then present our case study. A methods section follows our brief literature review.

\section{Police Deaths in the Line of Duty: A Question of Performance}

The role of police in contemporary society, especially in democratic societies, has been discussed for some time, and an infinite number of tasks are attributed to officers, be them legitimate or illegitimate, direct or indirect (Bengochea, Guimarães, Gomes \& Abreu, 2004; Bittner, 2003; Greene, 2002). Police officers' main responsibilities are to prevent criminal activities and apprehend those who break the law. These duties put them in frequent contact with suspects and offenders who are often hostile to police or other authorities, as the latter represent risks to their freedom or may prevent their illicit dealings (Schouten \& Brennan, 2016). As Schouten \& Brennan (2016) comment, the possibility of violent confrontations force police to adopt technical safety measures employed during policing activities.

Such measures are important to consider when police officers' actions result in the assault or death of alleged offenders, but also assume a fundamental importance when actions lead to police deaths. More than twenty years ago, King \& Sanders (1997) argued that when the circumstances of police deaths are objectively analyzed, most of the time, the officers killed on duty had committed some type of error when dealing with the subject who became his or her murderer. The authors further explain that such errors are almost always directly linked to the officer's diminishing work performance before his assassination.

Previous works, such as that of Taris (2006), confirm this diagnosis and explain that one of the factors responsible for performance lapses is stress, principally when it is chronic. This pathological condition is identified as Burnout Syndrome by authors such as, Costa, Accioloy Jr., Oliveira \& Maia (2007), Guimarães, Mayer, Bueno, Minari \& Martins (2014) and Oliveira \& Bardagi (2009). Common characteristics include: permanent physical and mental exhaustion, lack of professional perspective, and even questioning the meaning of one's work and life. Taris (2006) explains that this condition can significantly increase an officer's risk of becoming a victim because it reduces their physical or mental capacities with inevitable performance consequences.

Emotionally exhausted people have trouble investing the energy required to perform their jobs adequately. Attention deficit thus results in delayed reactions and an inability to respond correctly to severe situations (Hyeda \& Handar, 2011). Fundamental functions, such as planning, problem solving, and avoiding inappropriate responses, become extremely compromised due depressive symptoms, anxiety, and job dissatisfaction; taken together, this then increases lethality risks, aggression, and other violent acts when criminals are approached by or chased in high-speed vehicle pursuits (Ellrich, 2016).

As Ellrich (2016) explains, when police arrive at crime scene, they generally do not know what awaits them. Situations that initially appear low risk can quickly escalate into high-risk affairs and result in attacks on police. If officers are in good mental and physical shape, they can use their training and experience to maintain their calm and safety. For Ellrich (2016), when such capacities are lacking, police tend to falter when attempting to manage a tense situation, and violence becomes a likely outcome. The author further argues that violence could be avoided if the officer was in better physical and mental shape. The irritability, hostility, and agressivity that officers brings to already tense situations put their own lives at risk. Lack of self-control brought on by such Burnout Syndrome means the officer has a greater chance of attacking or being attacked.

Other causes of stress, related to the internal dynamics and operation of police institutions, are also identified in the literature. According to Chae \& Boyle (2013), communication problems between personnel at various levels in the police hierarchy, and lack of objectivity in periodic police evaluation (which officers are subjected to for career promotion) cause tension and stress. The authors explain that administrators and supervisors tend to conduct subjective evaluations to measure their subordinates' performance. In the process they often favor individuals based on how well they have assimilated into the police sub-culture-in detriment to others who behave strictly according to institutional standards and rules. Promotions are also often based on political influences as opposed to merit. All these factors contribute to stress in the institutional environment. These dynamics sometimes make officers feel as though their contributions are not appreciated by the institution-feelings that decrease work satisfaction and motivation. Meanwhile officer stress increases and they become more vulnerable while performing their policing duties.

Chae \& Boyle (2013) also state that work schedules, organized into long shifts, is a strong contributor to officers' poor performance. Indeed, fatigue impairs officers' ability to assess complex situations; exhaustion may limit the psychomotor functioning needed when confronted with psychologically stressful situations, such as those demanding the use of a lethal firearm.

In this regard, Donner \& Popovich (2019) explain that police-involved shootings can occur in a variety of situations, and that the officer's decision to shoot is often associated with his or her perceived risk of being killed or injured by an aggressor who is also armed (and willing to use deadly force to fend off the officer). Such conflicts 
come with an extremely high stress load; and when a police officer, whose performance is hindered due to personal or professional problems is placed in a tense situation, a higher number of fatalities occur compared to armed conflicts involving officers with acceptable performance levels.

Attempts to resist imprisonment are frequent and present serious risk to officers' physical integrity. For Edwards (1995), procedural errors, lack of attention to and negligence to safety precautions may be responsible for numerous on-duty police officer deaths. Thus, responding to a seemingly common call can turn into a confusing and dangerous situation, especially in cases where police are investigating drug trafficking. Officers participating in routine searches can also become vulnerable if they neglect safety precautions (Edwards, 1995).

King \& Sanders (1997) analysis shows that individuals who kill police more commonly do so to escape a situation (confrontation), as opposed acting on a deliberate intent to kill. Caplan, Marotta, Piza \& Kennedy (2014) further explain that factors determining risk are complex and related to both offenders' and police characteristics taken together with those of the environment. Territories that experience high crime rates concentrate criminal groups, drug traffickers, or other types of illicit trade, and generally provide suspects with good opportunities for evasion or attack during police confrontation. Therefore, they also present high risk to police during their operations. During an ambush, suspects on the run find refuge in poorly-light streets; outside of their element, officers not at their full physical and psychological capacity may not clearly perceive the risks that such a situation represents - thus, allowing the suspect take advantage of the characteristics of the terrain, and thereby attack or kill a pursuing officer.

According to Caplan et al. (2014), the local built environment is important to consider in risk assessment since certain structures can serve as trenches from which police advances can be curtailed, and at the same time, facilitate criminals' escape. The authors conclude that potential risks should be considered, not only in terms of people involved in the events, but also in the way the environment shapes and informs their behaviors.

For these authors, factors that make certain territories more potentially prone to attacks on police are not always simultaneously present; however, the ways in which various spatial factors combine in a given context can reveal consistent risk patterns. Therefore, risk of attack and death vary dramatically depending on the circumstances - since some places (at sometimes) may be seen by the offender as opportune for acting aggressively towards the police.

Just like urban residential and commercial areas, streets and highways are also vectors of mortality. Police chases, involving high-speed vehicles, are very dangerous, especially if we consider that training for this type of activity is generally precarious and lacking formal and strict protocols (Caldeira, 2011 \& Trindade \& Porto, 2011). According to these authors, police officers generally recognize such shortcomings and would like to receive more training. In fact, the potentially lethal effects of receiving inadequate training occur when safety equipment, such as seat belts, are not used or not used properly, on the grounds that they might disrupt mobility upon rapid exit from the vehicle if necessary.

The possibility of killing someone on the job is in itself a cause of stress. When this occurs, it tends to hinder police performance following the incident. According to Stack, Bowman \& Lester (2012), officers' psychosocial functioning tends to be significantly affected by fatalities; killings generate strong emotional responses from the victims' family members, from neighbors, from other the officers involved, from government officials, and the general public. Such situations are often followed by a period of debate and questioning, as many question the necessity of the death and whether it was justifiable. Police officers are often accused of using excessive force, especially when the suspect's weapon is not found, toy weapons are used, or when officers' lives were not at risk. Community reactions and demonstrations usually follow the incident, with strong implications for the policecommunity relationship. If the officers are under pressure, due to family and financial problems, stress levels may be enhanced, and their performance may be seriously compromised.

According to Chae \& Boyle (2013), a police officer with a weakened psychic structure, who experiences such an event, has a greater chance of developing a chemical dependency or displaying aggressive behaviors and suicidal tendencies. The authors comment that the same can occur when officers frequently experience sudden emotional transitions; abrupt transitions occur during police activities, such as, drug searches, stopping suspicious vehicles or armed confrontations.

These factors alone are not responsible for the poor performance that results in increased assaults on and killings of police officers. However, when several of these factors are present simultaneously and converge during a complex and dangerous police intervention, a strong possibility exists that their combined effect will compromise police performance and increase the probability of potentially lethal attacks.

\section{Behavior Deviance and Violence}

In addition to performance related factors, Pino \& Johnson (2011) attribute officer deaths to certain types of police behavior, which in some cases, exceed the limits of what is expected and considered acceptable; thus, they are generally referred to as misconduct or bad behavior. Such misconduct includes violations of civil and criminal laws and not adhering to the rules, regulations, and procedures established by the police institution itself. 
Police brutality, characterized by the excessive use of force and constraint and constitutional rights violations, is among the most common types of misconduct, and is particularly highlighted in the literature. Covington, HuffCorsini \& Corsini (2014) show that attacks on police officers are almost always accompanied by a strong negative perception of law enforcement officials. The authors comment that this hostility is generally linked to feelings of injustice — of feeling unjustifiably threatened or attacked. In this sense, moral outrage against any citizen or against a specific group, which bases its identity on politics, religion, race or gender, can cause a multiplicity of violent interactions potentially inducing risk for the officer.

Aggressive acts and violent behaviors invariably increase the tension already present in society, which is not necessarily linked to police interventions. Ellrich (2016) shows that tense confrontations between police and citizens, occurring in a climate of stress, make both police and citizens more susceptible to attack and victimization. According to Harris (2011) tension levels can be measured by citizens' primary complaints against police officers. In high stress situations complaints of threats by police, constraint, disrespect, and even lethal force, predominate. Research conducted by this author indicates that poor behavior, and specifically brutality, may be linked to the entrance of individuals who have personality disorder into the police force. To substantiate his claim, the author demonstrates that some of the police officers considered more problematic have displayed this tendency since the beginning of their careers.

A similar characteristic was found among police of the Pará Military Police, as shown in the work of Silva \& Souza (2016); thus, study reported that $24 \%$ of complaints sent to internal review are against police who are within the first five years of their careers. These authors also report that $17 \%$ of the officers under internal investigation for misconduct were between 20 and 25 years old.

In this regard, Harris' (2011) survey showed that rookie officers tend to be inappropriately proactive, and therefore more likely to slip into antisocial behavior, such as abusing authority and using inappropriate tacticsboth of which can be placed into a more general definition of brutality. Research by this author in the United States demonstrates that most police officers display a peak of inappropriate behavior early in their careers. In general, after their first years of professional activity and more experience, the number of complaints against them decreases. They argue that the peak of violence attributed to the novice officer is related to their need for affirmation - to show their more experienced colleagues that they are reliable and deserving of acceptance. Harris (2011) further explains that certain police officers, who are denounced for misconduct early in their careers, display a decline in such incidents mid-career, but demonstrate an increase late in their careers when they are closer to retirement.

Data presented in Silva \& Souza's work (2016) regarding incidences of misconduct by Pará Military Police show that most complaints $(43.6 \%)$ are directed against police in the age range of 41 to 50 years, who have served between 16 and 25 years in the police force.

To understand why police continue to use brutality throughout their careers, we must consider that in the peripheral neighborhoods of large Latin American cities, referred to as favelas, periferias, baixadas, bairros in Brazil, Venezuela and neighboring countries, citizens are widely accepting of brutality as long as it is directed to so called "bad people," those considered dangerous bandits (banditos). Thus, some public agents believe that their authority grants them the right to commit violence against individuals with such characteristics, thereby widening the limits of the discretion of internal investigations (Corbacho, Philipp \& Ruiz-Vega, 2008; Rodgers, 2009; Souza \& Reis, 2014).

It is logical that at some point, violence directed against members of the community, will reach a tipping point and result in attacks against the police. After all, their behavior is similar to that of any other criminal. Violent retaliation against the police usually occurs when brutality is used against innocent community members. When this occurs, public support for police brutality disappears, and the community becomes hostile, or at the least indifferent, to police attacks. These changes often coincide with episodes of corruption or a police officer's direct involvement in criminal activities.

Furthermore, several authors show that the circumstance of investigations, and how they are handled, can result in a loss the public's loss confidence in government institutions, including but not limited to police agencies. These include: investigations that pay little attention to serious crimes, focusing on minor crimes with arbitrary arrests and ineffective and time-consuming internal disciplinary procedures with unconvincing and innocuous results (Bagley, 2013, Kwak, San Miguel \& Carreon, 2012; Ruiz Vásquez, 2013). On the other hand, the weakening of institutions has led to the emergence and proliferation of paramilitary groups, popularly known in Brazil as milicias, which are partly composed of security agents from various agencies. Milícias first take power and justice into their own hands and then take control over the various criminal activities existing in the territories in their domain (Barcellos, Zaluar, 2014; Misse, 2011; Zaluar \& Conceição, 2007).

According to Deosaran (2002) and Pino \& Johnson (2011), in poor and marginalized communities, the belief that police are associated with criminals, or that they will leak citizens' denouncements of crime to criminals themselves, is common. These authors report recurring incidents of demands for payments to prevent suspects' arrest or to withhold evidence during judicial processes. Similarly, cases of protecting corrupt police officers when a member of the group is accused of a crime, such as kidnapping or injuring someone in a shootout, are also 
frequent. In this context of mutual cover-ups and police-criminal involvement, police provide protection for traffickers and sometimes even directly participate in the drug trade-facilitating drug transport by covering for traffickers or even handing over seized drugs or those in evidence warehouses, either fully or partially. It also relatively common for police officers to request payments for their services in a given community; in these cases, local merchants make such inappropriate payments to police and other security forces (Brito, Souza \& J.L.C. Brito, 2016).

This behavior, while not always criminal, is almost always improper and makes the police appear unjust and illegitimate. This is especially the case when officers impose differing degrees of severity according to their personal ties (to criminals) and the criminal's status. Some police officers apply maximum severity when pursuing minor offenses, and on the other hand treat more powerful criminals, responsible for a majority of crimes, with relative softness. According to Pino \& Johnson (2011), focusing on small crimes and being lenient with powerful criminals, makes the police themselves criminals; the blurred line between the two groups is a slippery slope, likely to lead, at some point, to police victimization.

Illicit and licit drug consumption is a key factor instigating police toward misconduct - and thus resulting in a greater probability of police victimization. Stinson et al. (2013) clarify that misconduct, directly or indirectly related to officers' drug use, becomes especially dangerous to their own physical integrity and to those involved in police interventions (e.g. through arrests, confrontations etc.). Critical thinking and good decision making, abilities related to performance, can become compromised while under the influence of drugs (either legal or illegal). In addition, the authors argue that when citizens discover that an officer is a drug user, it exponentially increases their mistrust in all police. People tend to perceive the officer as a prisoner of his own addiction, conclude he is committing a crime that he should be combating, and thus is not trustworthy.

According to Harris (2014), police often initiate a pattern of inappropriate behavior with less serious slips, which become more frequent and more severe over time. Corrupt officers often also use excessive force and display other forms of misconduct. We do not have a clear understanding of how training received at the police academy impacts daily work. However, for many, the real learning occurs on the job, and for some, this is more powerful than their formal training. This on the job learning, however, is influenced by the institution's internal values and the perspectives of the police subculture (Souza; Brito \& Barp, 2009). If an officer becomes involved with a police group engaged in illegal activities from the onset of his or her career, the individual is more likely to become involved in inappropriate or illegal behaviors from early on. This then increases the possibility of their being victimized, since they are subjected to the risks inherent in illicit activities as part of his routine.

In addition to the factors discussed above, Ellrich (2016) demonstrates that police's direct involvement with crime is related to career frustration; in particular, officers who feel hurt or unmotivated after not receiving a promotion or suffering a penalization, which compromised their career trajectory are more likely to become involved in illicit activities. The author also argues that closing oneself into a narrow group of contacts, made up almost exclusively of other police officers, makes officers intolerant toward citizens. At the same time, it promotes a certain tolerance toward the illicit behavior of their co-workers. Taken together, these dynamics increase the possibility of lethal interactions between criminals and police, where officers can either cause fatalities or be victims of them.

\section{Materials and Methods}

This work concerns the deaths of police officers of the Pará Military Police and analyzes data from the Pará State Secretary for Public Security on police mortality during the period of January 2010 December 2017. We sought to identify the conditions under which deaths occur and the factors that most directly contributed to these events. We analyzed data from the database of the Secretary of Intelligence and Criminal Investigations (Siac) of Pará State Secretary for Public Security (Segup) and the investigative procedures undertaken by the internal review board of the Pará Military Police and by the Homicide Division of the Pará Civil Police, totaling fifty-two registered deaths. We used quantitative and qualitative approaches, hoping to enrich our analysis given that the two methodologies are based on different paradigms. We believe that this option was of fundamental importance in elucidating our understanding of police mortality — something impossible with just one type of approach. We based this choice on the fact that quantitative and qualitative approaches are simultaneously distinct and complementary with respect to how they perceive social reality (Bryman, 2004 \& Ruiz, 2004).

To compare the number of homicides occurring within the general population with the number of on-duty military police death, we used the criminal index criminal (IC) for homicides in the general population (ICH pop), calculated using the equation ICH pop $=\left(\frac{\text { number of homocides }}{\text { Pará state population }}\right) \times 100000$, and the criminal index for homicides of on-duty military police officers $I C H P M=\left(\frac{\text { number of PM homocides }}{\text { total number of PMPA of ficers }}\right) \times 100000$. Results were organized and presented based on descriptive statistics procedures, which according to Silvestre (2007) are efficient in organizing and describing through synthetic indicators. 


\section{Results}

Figure 1 - Comparison of homocide rates in Pará state general population versus homocide indexes of Pará military Pará from January 2010 to December 2017.

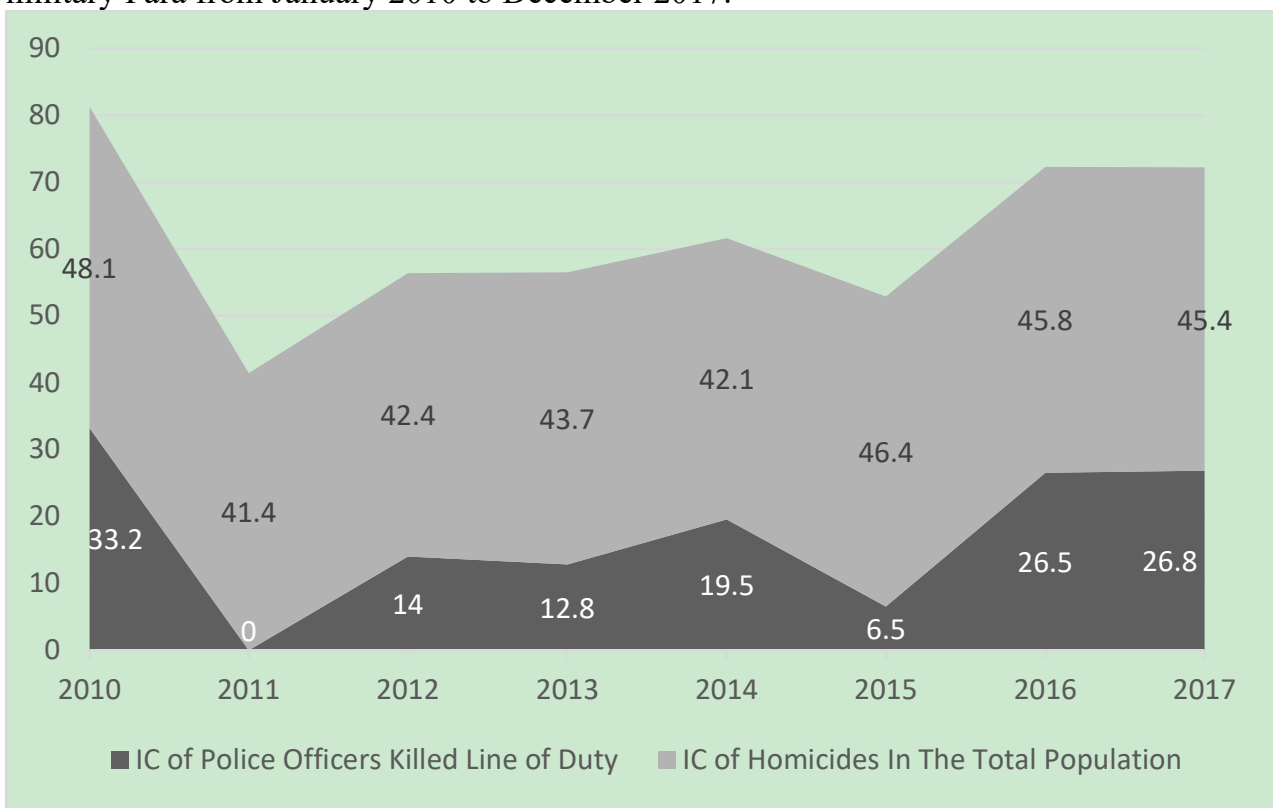

Source: IBGE-Brazilian Institute of Geography and Statistics and PMPA-Military Police of the State of Pará

According to data displayed on Figure 1, from January 2010 to December 2017, the homicide IC of Pará state varied between 41.4 and 48.1 homicides per 100,000, with an average of 44.4 per 100,00 inhabitants; meanwhile, the IC for on-duty PM varied from 0 to 33.2 homicides per 100,000 PM, reaching an average of 17.4 homicides per 100,00 PM. While the number of murdered officers is much lower for the entire period as compared to that of non-police officers, both are extremely high based on the World Health Organization (WHO) indicators. The WHO categorizes epidemic regions as those with rates higher than 10 murders per 100,000 inhabitants (Nielsen, 2009). Per this definition, the entire state of Pará, and all Brazilian states, would be considered areas of epidemic murder rates. Even if we just consider the police murder rate, which is significantly lower in relation to the rest of the population, it is still considered epidemic, as it surpasses the WHO parameters.

Figure 2 - Causes of on-duty military police deaths from January 2010 to December 2017 in Pará state

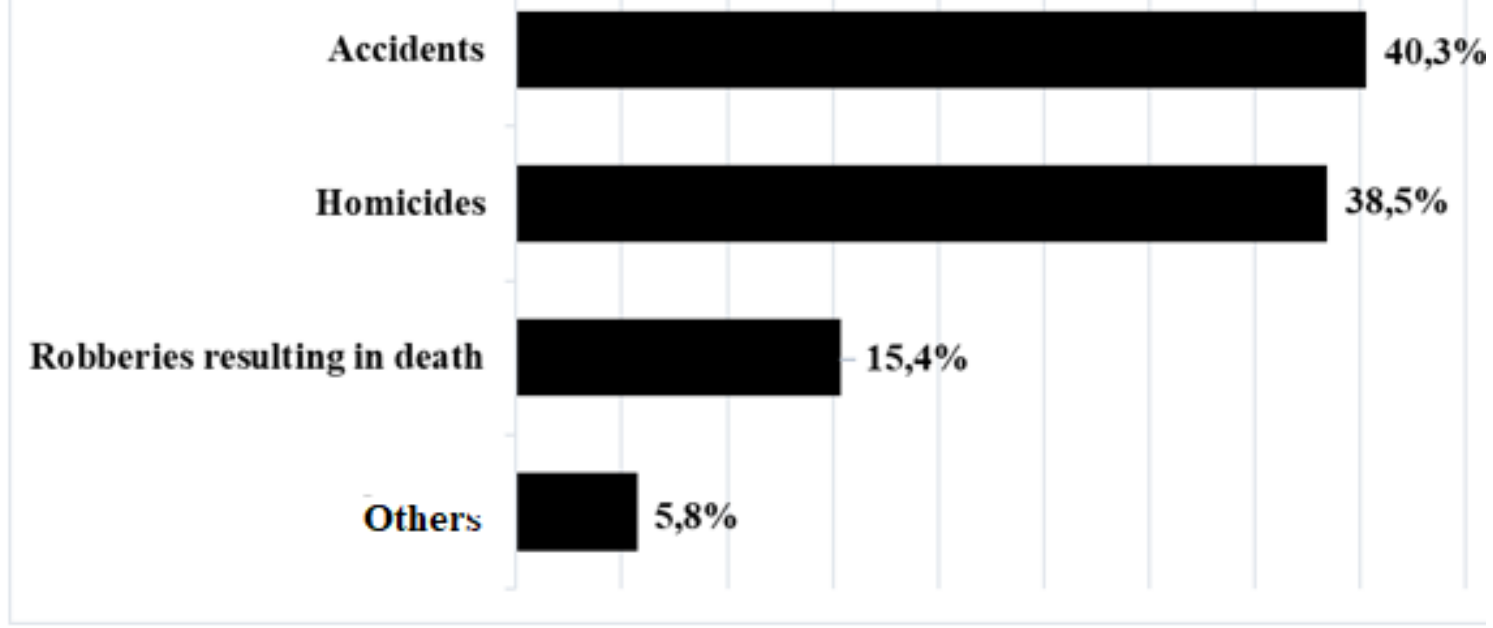

Source: PMPA-Military Police of the State of Pará

Figure 2 displays the causes of death of Pará police officers killed on-duty from January 2010 to December 2017. Police deaths due to accidents accounted for $40.3 \%$ all the total; following this, homicides account for $38.5 \%$ of all deaths (available data do not allow us to understand how many of these murders were conducted simply because victims were law enforcers or if they were related to performace flaws, or if they were directed at specific officers with a history of misconduct and involvement in illict activities); obberies resulting in death (latrocínio) appears in third place, accounting for $15.4 \%$ of on-duty police deaths; here, it is impossible to determine with 
precision if attacks on police were conducted to obtain the officer's firearm (generally the stolen object), or if gun theft was an accidental consequence of an action that resulted in murder (the true intention of the perpeutrator).

It should be noted that the circumstances surrounding some of the killings, which initially appeared as homicides, were not the result of police interventions. We verified that four events recorded as homicides refer to accidental shootings, deaths leading from crimes of passion, or incidents where information on the circumstances of the deaths is unavailable. Failure to properly record such events inflates the numbers in this category.

Figure 2 shows a distinction between homicides and latrocinios. Available date do not allow us to confirm with absolute precision that all robberies were done with the intent to obtain the officer's firearm. It is possible that the incidents refer to common cases of theft that ended in fatalities either due to the officer's (ineffective) response, or that the criminal recognized the officer as a law enforcement agent (which motivated the murder). While homicides represent the largest percentage of on-duty deaths, we must also recognize that other causes account for this high percentage. Thus, we can infer that is a considerable probablity that deaths can be attributed to officers' performance flaws, as described by Caldeira (2011), Chae \& Boyle (2013), Edwards (1995), Trindade \& Porto (2011) - as opposed to deliberate attempts to eliminate police officers, as the works of Duarte (2019) and Mello (2015) suggest.

Additional survey data indicate that for the period analyzed, on-duty deaths mainly occurred among police officers at the lower ranks (privates, corporals and sargeants). Concentration in these ranks is linked to their greater exposure - since agents at these levels are the uniformed officers who do on-foot or vehicle-based patrolling. This aspect is in line with the findings of Caplan et al. (2014) and Donner \& Popovich (2019).

Data on the circumstances in which the deaths occurred indicate that on-duty accidents are extremely significant. Events include vehicle accidents during police chases, a boat accident (occurring in the Naval division of the Pará Military Police), in addition to firearm accidents during training. Police officers killed in lethal clashes with criminals are due to shootings and attacks on police during service, such as during blitzes, when confronting suspects, or when police intervene in criminal assaults and ambushes.

Executions may also occur when a police officer is present at a crime scene and is disarmed and murdered before he could react. Police stress can also lead to misunderstandings and passionate conflicts, which as Costa et al. (2007), Guimarães et al. (2014) and Oliveira \& Bardagi (2009) suggest, contribute to an array of vulnerabilities to which the police are subjected. Executions must be highlighted since they do not exclusively effect police officers. Cases where witnesses present at the scene of a robbery, such as a shop, a residence or a public transport, are murdered to prevent them identifying the perpetrators and reporting them to the police, also exist.

\section{Conclusion}

Data and discussion presented here predict that problems related to poor police performance, due to inadequate mental and physical conditions lead to procedural errors associated with high levels of mortality-both for police and community members. Errors motivated by stress, lack of motivation, domestic problems, or negligence of basic safety protocols are factors that determine the conditions that make police more vulnerable and susceptible to victimization. Police are not passive receptors of violent circumstances; their actions are the result of an interactive process, where they interpret the situation and decide how to react.

Police work is extremely stressful, characterized by the presence of unpredictable events, exposure to trauma and extensive periods of boredom during long shifts, and to conflicts associated with organizational dynamics (Chae \& Boyle, 2013). These conditions force officers to put up with multiple stress factors, which eventually detract from their technical training and officers then neglect to follow safety protocols. In this way, the death of on-duty police officers is according to Tiesman et al. (2015) associated with risks produced by a familiarity with everyday tasks - a familiarity that can make officers negligent to work associated risks.

Police at the highest levels of the Pará Military Police insist that police deaths increased after the institution distributed basic equipment kits, which, in addition to common gear, includes semi-automatic weapon (Duarte, $2019 \&$ Mello, 2015). These officers believe that carrying of semi-automatic weapons caused more deaths because they became coveted by criminals who allegedly attack officers to obtain their guns. Yet, latrocinios attribute to a mere $13.7 \%$ of police deaths; thus, these numbers do not substantiate the above claims.

Excluding performance elements, to which we can also include accidents, and if we also consider that the circumstances surrounding police deaths a very occurred did not have detailed are poorly described in the Pará Military Police database, we can infer that a considerable number of murders may related police misconduct. Pino \& Johnson (2011) emphasized the importance of this factor, which involves, on the one hand, corruption and close personal involvement with criminals and, on the other hand, difficulties in their relationships with citizens and brutality.

Our results do not support the speculation criminals deliberately hunt down police or that their deaths are the result of attempting to steal officers' weapons, as a way of increasing criminals' firepower - or as a symbol or their power. In fact, mortality rates suggest exactly the opposite, showing that the current rates of police deaths are an absolutely foreseeable consequence of the type of work they carry out, and the negligence of safety procedures 
that could minimize the risks to which they are subjected in their daily work. In terms of the liaisons between police and criminals, and the role that these relationships play in police homicide rates, we believe that deeper investigations and new studies could bring about more consistent empirical responses than those we were capable of presenting at the moment.

\section{References}

Anuário Brasileiro de Segurança Pública. Retrieved from: http://www.forumseguranca.org. br/wpcontent/uploads/2017/01/Anuario_Site_27-01-2017-RETIFICADO.pdf.

Bagley, B. M. (2013). The evolution of drug trafficking and organized crime in Latin America. Sociologia, Problemas e Práticas, 71, 99-123.

Barcellos, C. \& Zaluar, A. (2014). Homicídios e disputas territoriais nas favelas do Rio de Janeiro. Revista de Saúde Pública, 48(1), 94-102.

Bengochea, J. L. P., Guimarães, L.M, Gomes, M.L. \& Abreu, S. R. (2004). A transição de uma polícia de controle para uma polícia cidadã. São Paulo em Perspectiva, 18(1), 119-131.

Bittner, Egon. (2003). Aspectos do trabalho policial (Policy and soceity series, n. 8). São Paulo: Edusp.

Brito, D.C., Souza, J.L.C \& Brito, D.M.C. (2016). Anomalias da política de segurança pública: A prática da catação e o policiamento. Planeta Amazônia: Revista internacional de direito ambiental e políticas públicas, $8,43-61$.

Bryman, A. (2004). Quantity and quality in social research. New York: Taylor \& Francis.

Caldeira, T.B. (2011). A problemática das perseguições motorizadas: Num contexto ético-social. 2011. (Master's thesis). Instituto Superior de Ciências Policiais e Segurança Interna, Lisboa, Portugal.

Caplan, J.M., Marotta, P.L., Piza, E. L. \& Kennedy, L.W. (2014). Spatial risk factors of felonious battery to police officers. Policing: An international journal of police strategies \& management, 37(4), 823-838.

Chae, M.H., Boyle, D.J. (2013). Police suicide: Prevalence, risk, and protective factors. Policing: An international journal of police strategies \& management, 36(1), 91-118.

Corbacho, A, Philipp, J. \& Ruiz-Vega, M. (2015). Crime and erosion of trust: Evidence for Latin America. World Development, 70(C), 400-415.

Costa, M., Accioly, H., Oliveira, J. \& Maia, E. (2007). Estresse: Diagnóstico dos policiais militares em uma cidade Brasileira. Revista Panamericana de Salud Pública, 21(4), 217-222.

Covington, M.W, Huff-Corzine, L. \& Corzine, J. (2014). Battered police: Risk factors for violence against law enforcement officers. Violence and Victims, 29(1), 34-52.

Cruz, J.M. (2011). Criminal violence and democratization in Central America: The survival of the violent state. Latin American Politics and Society, 53 (4), 1-33.

Deosaran, R. (2002). Community policing in the Caribbean: Context, community and police capability. Policing: An international journal of police strategies \& management, 25(1), 125-146.

Donner, C.M. \& Popovich, N. (2019). Hitting (or missing) the mark: An examination of police shooting accuracy in officer-involved shooting incidents. Policing: An international journal of police strategies \& management, v. 42, n. 3, p. 474-489.

Duarte, E.N.P.M. (2019). O risco não cessa quando o turno termina: Um estudo sobre a morte de policiais militares fora do serviço. (Master's thesis). Federal University of Pará, Belém, Brazil.

Edwards, T. D. (1995). Felonious killings of state police and highway patrol officers: A descriptive and comparative evaluation. American Journal of Police, 14(2), 89-105.

Ellrich, K (2016). Burnout and violent victimization in police officers: A dual process model. Policing: An international journal of police strategies \& management, 39 (4), 652-666.

Greene, J. R. (2002). Administração do trabalho policial: Questões e análises (Policy and society series, n. 5). São Paulo: Edusp.

Guimarães, L.A., Mayer, V.M, Bueno, H.P.V, Minari, M.R.T. \& Martins, L. F. (2014). Síndrome de Burnout e qualidade de vida de Policiais Militares e Civis. Revista Sul Americana de Psicologia, 2(1), 98-122.

Harris, C. (2011). Problem behaviors in later portions of officers' careers. Policing: An international journal of police strategies \& management 34 (1), 135-152.

Harris, C. (2014). The onset of police misconduct. Policing: An international journal of police strategies \& management, 37 (2), 285-304.

Hyeda, A. \& Handar, Z. (2011). Avaliação da produtividade na síndrome de Burnout. Revista Brasileira de Medicina do Trabalho, 9(2), 78-84.

IBGE - Instituto Brasileiro de Geografia e Estatística. Retrieved from https://www.ibge.gov.br/.

King, W. R., \& Sanders, B. A. (1997). Nice guys finish last: A critical review of killed in the line of duty. Policing: an international journal of police strategies \& management, 20(2), 392-407.

Kwak, Dae-Hoon, San Miguel, C.E. \& Carreon, D.L. (2012). Political legitimacy and public confidence in police: An analysis of attitudes toward Mexican police. Policing: An international journal of police strategies \& 
management, 35 (1), 124-146.

Malone, M.F.T. (2013). Does crime undermine public support for democracy? Findings from the case of Mexico. The Latin Americanist, 57(2), 17-44.

Mello, C.M.A. (2015). "Mesmo com o sacrificio da própria vida”: A multiplicidade dos riscos na profissão policial militar. (Master's thesis). Federal University of Pará, Belém, Brazil.

Misse, M. (2011). Crime organizado e crime comum no Rio de Janeiro: Diferenças e afinidades. Revista de Sociologia e Politica, 19(40), 13-25.

Nielsen, A. (2019). Não há mais lugar seguro: Criminalidade avança pelo interior do País. Desafios do Desenvolvimento: Revista de informações e debates do Instituto de Pesquisa Econômica Aplicada, 52, 1. Retrieved from http://www.ipea.gov.br/desafios/index.php?option=com_content\&view=article\&id=1245:reportagensmaterias\&Itemid $=39$.

Oliveira, P. L. M. D. \& Bardagi, M.P. (2009). Estresse e comprometimento com a carreira em policiais militares. Boletim de Psicologia, 59(131), 153-166.

Pino, N.W. \& Johnson, L.M. (2011). Police deviance and community relations in Trinidad and Tobago. Policing: An international journal of police strategies \& management, 34(3), 454-478.

Reis, J.F.G. \& Souza, J.L.C. (2016). Grandes projetos na Amazônia: A hidrelétrica de Belo Monte e seus efeitos na segurança pública. Dilemas: Revista de estudos de conflito e controle social, 9(2), 215-230.

Rodgers, D. (2009). Slum wars of the 21 st century: Gangs, mano dura and the new urban geography of conflict in Central America. Development and Change, 40(5), 949-976.

Ruiz, F.M. (2004). Pesquisa qualitativa e pesquisa quantitativa: Complementaridade cada vez mais enriquecedora. Administração de Empresas em Revista, 3, 37-47.

Ruiz Vásquez, J.C. (2013). Colombian police under fire: Image, corruption and controls. Policing: An international journal of police strategies \& management, 36(2), 399-420.

Schouten, R. \& Brennan, D.V. (2016). Targeted violence against law enforcement officers. Behavioral Sciences \& the Law, 34(5), 608-621.

Silva, J.V.B. \& Souza, J.L.C. (2016). Criminalidade policial: A dinâmica da relação entre violência e corrupção na Polícia Militar do Pará. Cadernos de Estudos Sociais, 31(1), 99-117.

Silvestre, A.L. (2007). Análise de dados e estatística descritiva. Lisboa: Escolar Editora.

Souza, J.L.C., Brito, D.C. \& Barp, W.J. (2009). O segredo institucional e a manipulação da informação em Goffman. Revista de Ciências Sociais, 40(2), 47-61.

Souza, J.L.C. \& Reis, J.F.G. (2014). A discricionariedade policial e os estereótipos suspeitos. Revista do NUFEN, 6(1), 125-166.

Souza, J.L.C., Brito, D.C. \& Barp, W.J. (2017). Drogas e crimes: Desafios da segurança pública no Estado do Pará. Belém: Paka-Tatu, 2017.

Stack, S., Bowman, B. \& Lester, D. (2012). Suicide by cop in film and society: dangerousness, depression, and justice. Suicide and Life-Threatening Behavior, 42(4), 359-376.

Stinson, P.M., Liederbach, J., Brewser, Jr., S.L., Schmalzried, H. D., Mathna, B. E. \& Long, K. L. (2013). A study of drug-related police corruption arrests. Policing: An international journal of police strategies \& management, 36 (3), 491-511.

Taris, T.W. (2006). Is there a relationship between burnout and objective performance? A critical review of 16 studies. Work \& Stress, 20 (4), 316-334.

Tiesman, H. M, Heick, R.J., Konda, S. \& Hendricks, S.A. (2015). Law enforcement officers' risk perceptions toward on-duty motor-vehicle events. Policing: An international journal of police strategies \& management, $38(3), 563-577$.

Tiesman, H. M., Hendricks, S.A, Bell, J.L. \& Amandus, H.A. (2010). Eleven years of occupational mortality in law enforcement: The census of fatal occupational injuries, 1992-2002. American Journal of Industrial Medicine. 53(9), 940-949.

Trindade, A. \& Porto, M.S.S.G. (2011). Monitoring police activity: A comparative analysis of codes of ethics in Brazil and Canada. Sociologias, 13(27), 342-381.

Zaluar, A \& Conceição, I.S. (2007). Favelas sob o controle das milícias no Rio de Janeiro. São Paulo em Perspectiva, 21(2), 89-101. 